\title{
Regional development banks in the world economy
}

Judith Clifton, Daniel Díaz Fuentes and David Howarth

This is an authors' pre-print version. Please reference as: Clifton, J., Fuentes, D. and Howarth, D. 'Regional development banks in the world economy', in Clifton, J., Fuentes, D. and Howarth, D., eds. Regional Development Banks in the World Economy, Oxford: OUP, 2021, pp. 1-32.

\section{Why study regional development banks, and why now?}

This volume focuses on regional development banks (RDB) and provides a comprehensive, comparative and empirically informed analysis of their origins, evolution and contemporary role in the world economy. A volume on RDB is timely for four major reasons. First, since their establishment, the importance of RDB lending has increased significantly. To illustrate, the European Investment Bank (EIB) alone lent more overall than the World Bank, the world's largest global multilateral development bank (MDB), from 1991 onwards (Clifton et al. 2014 and 2017b). Even when specific RDB lend less in total than their MDB counterparts, the loans that these RDB make to their member states are often larger than the loans received from MDB. ${ }^{1}$ In other words, RDB may be more

${ }^{1}$ This higher volume of RDB compared to MDB lending to member countries is seen notably in a number of Latin American and Asian RDB. For the Central American Bank for Economic Integration (CARIBEI) see Deras et al. this volume; for the Andean Financial Corporation (CAF) see Brando, this volume; and for the Asian Development Bank (ADB) see Barjot and Lanthier, this volume. 
important to their regions than the MDB.

A second reason for the timeliness of this volume is that RDB have experienced a renaissance over the past few years. In the age of what Angus Maddison and the OECD (2010) label 'Shifting Wealth', we are witnessing the relative decline of the West and the rise of new economic powers in the East and South. Global MDB and most RDB were established during a specific historical moment — at the end of the Second World War and over the following decade - and their governance and shareholder structures reflect this specific political-economic juncture. As the relative size of member state economies shifts, along with their political clout or even military might, a major question is the extent to which the incumbent banks' governance and shareholder arrangements will be changed to reflect this development (Ravallion 2016). Jakob Vestergaard and Robert Wade (2013, 2015) argue that there has been determined resistance from the US, Japan and a number of European governments to power sharing with rising economic powers within the World Bank and IMF. The debate over power sharing is only going to intensify as the economic and political weight of players in the East and South, and particularly, the People's Republic of China (PRC), increases (Mahbubani 2013). This re-assertion of East and South has included the establishment of new national and regional development banks. In particular, the creation of the Asian Infrastructure Investment Bank (AIIB) can be explained in large part to Chinese government frustration with the operation of existing RDB and global MDB and as an expression of Chinese ambitions for the future $\mathrm{Xu}$, this volume).

A third reason for the timeliness of this volume is that RDB remain under-researched, when compared, for example, to global MDB. Of the existing body of academic work on RDB, the main focus has tended to be the principal advantages of RDB in comparison to global 
MDB (Griffiths-Jones et al. 2008). A major line of analysis associated with this literature is the extent to which RDB have advantages associated with greater geographical, economic and cultural proximity with regard to their shareholders and the countries to which they provide loans, than global MDB. RDB are thought to be better positioned to give voice to their members, especially to small or medium-sized countries, which may otherwise struggle to be heard in global MDB. This in turn leads to the expectation that RDB are better placed to respond to the needs and demands of their members. RDB are also considered to be more flexible, relying often on informal mechanisms of peer pressure, as opposed to harder conditionality. Furthermore, RDB are thought to present an arena whereby agreements through negotiation are easier than in global MDB, largely based on the assumption that members are both lenders and borrowers (Griffith-Jones et al. 2008). Given the increased importance of RDB it is important to study them on their own terms.

Fourth, the time is ripe to examine RDB in the context of the aftermath of the international financial crisis and the Great Recession of the late 2000s, as criticism of the role of both global MDB and RDB has intensified. This recent wave of criticism is not unprecedented. Each major international economic and financial crisis that occurred since the Second World War triggered a reassessment of the very foundations and sustainability of global MDB and RDB. The first wave of criticism emerged in parallel to the debt crisis after the collapse of the Bretton Woods system in the 1970s (Babb 2013). Criticism intensified again in the aftermath of the Cold War in the 1990s, with the collapse of most political regimes that had pursued a command economy, particularly the Union of Soviet Socialist Republics (USSR), followed by their economic transition to a form of capitalism and an era of rapid globalisation. Since the 2008 crisis — which mainly affected the richest countries, notably the United States (US) and in Europe - critics have asserted that development banks did not do enough (Griffiths Jones et al. 2008). Beyond crisis-related challenges, questions 
have been asked with regard to what extent global MDB and RDB perform in a manner that corresponds satisfactorily to their original mandates, particularly, that of development. To what extent has the role of banks become increasingly influenced by private forces. Has 'mission creep' occurred? Recommendations have also been made with regard to how global MDB and RDB can use public finance more efficiently to reconstruct, develop and innovate economies around the world, and to identify mechanisms and institutions to overcome and, preferably, avoid, future crises (see Cuesta and Alonso, this volume).

In the next section, we present the categories and the analytical framework that we apply to examine RDB, and specifically a form of rational choice institutionalism-PrincipalAgent analysis. In the third section, we apply the categories and framework to each RDB in its specific political economy context, with a view to setting out and analysing the similarities and differences among RDB. We demonstrate and explain an important evolution in the main objectives of $\mathrm{RDB}$ lending activities over three distinct periods: from regional integration and development, to market promotion and development, and then to geographical expansion — and multi-polarity promotion for some RDB — and a more strategic interventionism in the market, that includes market shaping activities including industrial policy. We explain this evolution in terms of the agency of the RDB in relation to their multiple principal - the shareholder national governments.

\section{Regional development banks: A framework for analysis}

Our analytical framework builds on — extends and updates—previous studies of RDB, in particular White (1970 and 1972) whose volumes on RDB cover only those in the Global South. White (1970) classified RDB in geographical-functional terms. Starting with geographical considerations, some definitions are required. The term 'region' is 
understood as constituting a unit of analysis with broadly similar geographical, historical, culture and political features. The largest unit to which the term region could be applied is the 'continent' (White 1970: 22), of which, according to definitions, there are between five and seven. Below the unit of the region is the 'sub-region', understood as a group of countries that agree to cooperate. The first period of 'Continental RDB' creation included the Inter-American Development Bank (IABD), the African Development Bank (AfDB) and the Asian Development Bank (ADB). 'Sub-regional RDB', on the other hand, consisted of members of a region who decided to cooperate to establish a development bank; this was the case for the CABEI and CAF. ${ }^{2}$

2 This volume does not cover all RDB. In particular, it does not analyse small sub-regional RDB, such as those in the Caribbean and Africa, which were created with the aims of contributing to the decolonisation process, or maintaining monetary stability and financial links with their former colonial powers. This volume omits, for example, the Caribbean Development Bank (CDB), established in 1970, originally constituted by 16 economies (including dependent British Overseas Territories) that held 60 per cent of the voting shares as well as the United Kingdom and Canada, which held the remaining 40 per cent, in their capacity as non-regional donor members. Although the $\mathrm{CDB}$ is associated with the Caribbean Community (CARICOM), established in 1973, the CBD does not have mandates or functions in CARICOM as a Sub-Regional Integration RDB. Other RDB not covered in this volume include a group of Sub-Regional RDB which emerged in Africa to support currency unions in former British and French colonies. Cases include the East African Development Bank (EADB), the West African Development Bank (BOAD) and the Development Bank for Central African States (BDEAC). The EADB was established in 1967, by Kenya, Tanzania and Uganda, to promote cooperation in the East African Community (EAC). As a result of regional conflicts, the EADB and the EAC disintegrated 
With regard to functions, the Continental RDB - the IABD, ADB and AfDB - all focused on promoting development across most of — but not all — the countries in their respective continents. Both donors and recipients were found within the continent. However, where asymmetry existed, the donor would be typically outside the continent, lending to the recipient within the continent. In contrast, the major function of the Sub-regional RDB would be to promote integration as well as development among the members of the club, a task that often included supporting the poorest members. Hence, when established, the

in 1977 and were re-established in 2000, adding Rwanda in 2008. BOAD was established in 1973 by the country members of the West African Monetary Union (1959) through the Central Bank of West Africa (BCEAO) as shareholders. From 1994, BOAD became a specialised financial institution to attain the objectives of the West African Economic and Monetary Union (WAEMU), including Benin, Burkina-Faso, Côte d'Ivoire, Guinea Bissau, Mali, Niger, Senegal and Togo (IMF 2018). The BDEAC was established in 1977 by members of the Economic and Monetary Community of Central Africa (CEMAC), which included Cameroon, Central African Republic, Chad and Guinea Equatorial, Republic of the Congo and Gabon (IMF 2018). A further set of small but notable RDB not covered in this book are the Council of Europe Development Bank (1956), which is oriented to social and emergency projects, and the Nordic Investment Bank (NIB), created in 1975 by Denmark, Finland, Iceland, Norway and Sweden. Finally, this volume does not include other development banks the membership of which is based on religious and legal principles, such as the Arab Bank for Reconstruction and Development (1974), which includes 18 members of the League of Arab States, and the Islamic Development Bank (1975) which includes 57 countries across four continents. 
IABD, the AfDB and the ADB could be classified as Continental RDB, and the EIB, CABEI and CAF as Sub-regional-integration RDB.

Based on this initial classification, our study updates and expands on the original work by White (1970). We take into consideration the historical context of the constitutive moment when each RDB was established, and track and evaluate the subsequent evolution of the major RDB. We include in our analysis those major RDB in the Global North. To track the evolution of RDB, we consider the changing nature of cooperation and conflict in the international system in which the RDB have existed, which have shaped both the global and regional economies, contributing to both enhanced economic and political integration and, occasionally, disintegration, of the world's regions. Post-colonialism also influenced the emerging RDB. From the end of the Second World War to the 1980s, most international cooperation through RDB was driven by regionalism, and political and military rivalry between the West and the East. Later, in the post-Cold War period, international cooperation became characterised by globalisation, a mistrust of government intervention at the national and international levels, and a relatively open multilateral regionalism among heterogeneous members - including countries with different levels of development and with often, considerable, geographical distance between them. Most recently, the shift of wealth to the East and South has resulted in an increasingly 'multipolar' world economy, characterised by the relative decline of both the economic weight and political influence of Western countries and the emergence or re-emergence of new players.

These shifts in the world economy had a significant impact upon the establishment and subsequent evolution of RDB. We specify five RDB functions-development, regional integration, market promotion, multi-polarity reinforcement and interventionist market shaping, or, industrial policy — which have risen and declined in relative and real 
importance over time. There were three historical junctures when RDB were established. The first period of their creation, from the 1950s to the 1960s, was covered by Singh (1968) and White (1970 and 1972). First, there were Continental RDB which promoted development across most countries in the continent in which they were based. This function responded to the objectives defined by political elites working in the specific continental context, for example, within a continentally-focused organisation, in the Americas, Africa or Asia. The second major function undertaken by some RDB was to promote sub-regional integration as well as development. Integration included both negative integration - the elimination of, inter alia, tariff and nontariff barriers - and positive integration - the creation of common rules, infrastructure and public goods (Cook and Sachs 2019).

These development banks were established officially to correct for market failure. RDB provided long-term and high-risk financing to advance public policy objectives - and notably the construction of basic infrastructure that provided for positive externalitieswhere commercial banks and private capital markets were unwilling or unable. This kind of market failure was particularly acute in developing countries where investment risks could be significant and financial markets underdeveloped. Furthermore, national government fiscal resources, national development banks or other state-owned financial institutions - especially those in the developing world—often lacked sufficient capital to finance large infrastructural projects. Official development assistance from international bodies or other national governments was too piecemeal with the bulk directed to social sectors. Thus, RDB filled an important funding niche.

The second major period of RDB creation occurred in the 1990s. In this period, the function prioritised by newly established RDB was associated more closely with activities 
promoting market forces and a withdrawal of state intervention in national economies. In addition, already existing RDB also embarked - albeit unevenly-on more marketoriented functions. These functions involved RDB placing emphasis on the use of finance to support and promote private activities in the markets, towards increased competition and privatisation. Hence, the original Continental and Sub-regional-integration RDB of the first period transformed into banks that pursued 'market-led development' - whilst keeping their continental and sub-regional integration functions. This shift towards marketled development was particularly manifested in the so-called Washington Consensus approach (Caroll et al. 2019), that influenced most of the existing RDB, including the IADB (as demonstrated in Babb and Lopez and Rougier, this volume), the AfDB (as seen in Kraemer, this volume), and ADB (as shown in Barjot and Lanthier, this volume). Market-led development also influenced Sub-regional-integration RDB, including CAF (Brando, this volume), CABEI (Deras et al, this volume) and, to a lesser extent, the EIB (Clifton et al. 2014 and Clifton et al. this volume). Market-led development inspired particularly the newly established EBRD for central and eastern Europe and central Asia (see Shields and Roper, this volume). Hence, in this second period, Continental RDB were transformed into 'Continental market-led' RDB whilst Sub-regional-integration RDB were transformed into 'Sub-regional market-led integration' RDB.

Finally, in the most recent period of RDB creation and evolution from the beginning of the Twenty-First Century, a more ambitious geo-political and market-shaping approach can be detected. Geo-political ambition is most evident in the establishment of the AIIB under Chinese government leadership. Furthermore, a number of existing RDB which had previously focused mainly on their immediate region became increasingly active beyond that region. Hence, Continental RDB have expanded their borrowing and lending beyond their continent (to become '+Continent'). Where there is asymmetry between donor and 
recipients, it is often in the opposite direction as before - that is, increasingly, the donor is based within the continent whilst the recipient is beyond the continent. Regarding Subregional $\mathrm{RBD}$, geographically, these, likewise, have tended to become much more active beyond their club members, with regard to both borrowing and lending (to become '+Subregional'). Hence, both kinds of RDB have expanded geographically outside of the original unit of analysis.

With regard to function, RDB have continued to develop the continent / region and pursued market-oriented activities - while extending these activities beyond the continent / region. At the same time, over the past decade, we detect a greater caution with regard with neoliberal market creating policies: a number of RDB have also reasserted or rediscovered the merits of a more interventionist investment policy, including industrial policy. RDB have gone beyond the correction of market failure - and notably the absence of financial services willing to invest in large infrastructure projects, especially in developing countries - and engaged in market shaping (Mazzucato and Penna 2015). A number of RDB have become engaged in long-term strategic development of entire industrial sectors. These RDB have emerged as what we label '+Continental strategic market' RDB and '+Sub-regional strategic market integration'. Both kinds of RDB have expanded geographically outside of the original area of financing and lending, whilst their functions have gravitated further towards more interventionist market shaping activities including industrial policy.

By way of illustration of these geographical and functional developments, we can take the case of the EIB. Originally established as a Sub-regional RDB to promote integration in Western Europe, the EIB from the 1990s, whilst remaining a Sub-regional-integration RDB, expanded strongly into market-promoting functions, especially from the 1990s, 
whilst also lending outside the sub-region. In recent years, the EIB has also engaged in a putative industrial policy through the European Commission's Investment Plan for Europe and European Fund for Strategic Investment. Another example is CAF, also originally a Sub-regional-integration RDB, this time among the Andean Group national economies, which expanded its shareholders and lending activities significantly beyond its original club of members, whilst its function moved towards market promotion, albeit to a lesser extent than the EIB. Again, in the more recent period, $\mathrm{CAF}$ has seen a reassertion of a more interventionist market shaping and industrial policy.

An analytical framework drawn from the political science and political economy literature assists our examination of the operation of RDB and their development: the Principal-Agent approach - a version of Rational Choice Institutionalism. To what extent can PA shine a light on these geographical and functional transitions? For many years, Neo-Liberal Institutionalism and Intergovernmentalism dominated the scholarship on the role and development of international organisations (IOs) in International Political Economy (IPE). However, over the past two decades, a greater diversity of approaches has been applied. An influential rationalist analytical framework adopted to analyze the role and development of IOs and issues in the politics of international finance and economics more generally has been the Principal-Agent approach (Hawkins et al. 2006; Vaubel 2006). Through delegation to an agent, principal(s) hope to manage externalities, facilitate collective decision making, resolve disputes, enhance credibility, and/or lock-in commitments (Kiewiet and McCubbins 1991; McCubbins and Schwartz 1984; Weingast and Moran 1983).

The Principal-Agent approach has been used to study the evolution of conditionality in approving loans to member states of the IMF (Martin 2006), American foreign aid policy (Lyne et al. 2006), and negotiations in the WTO (Elsig 2011), and the political economy of 
financial liberalisation (Singer 2007). Most relevant to our analysis of RDB, the approach has also been applied to explain changes in the World Bank's lending portfolio (Nielson and Tierney 2003; see also Vaubel 2006). The added value of the Principal-Agent approach is in explaining puzzles where a group of member states are seemingly willing and potentially able to control the action of an IO but fail to do so. Since Principal-Agent analyses focus upon the strategies of rational actors it is particularly relevant when analyzing short- and medium-term action, when actors' preferences and interests are fixed.

One of several unique features of delegation at the international level is that this involves multiple principals and, specifically national governments (Hawkins and Jacoby 2006, Nielson and Tierney 2003). In the case of global MDB and RDB, these national governments are shareholders, the relative influence of which is determined in large part by the national share. While national shareholders have involvement in the governing boards of global MDB and RDB, this involvement will vary by institution. The 'board of directors' of the global MDB and RDB will have some degree of autonomy — which again varies by institution - to manage the day-to-day affairs of the bank. The agreed preferences of the member state shareholders are set out in the terms of delegation-often referred to as Articles of Agreement. However, these terms will never provide precisely defined rules according to which the agent (the bank) will have to operate in all situations. Thus, the agent will have to use its discretion to adopt policies (inter alia, on funding sources and loans) in a manner that is deemed to correspond to the preferences of the multiple principal.

The principal(s) and the agent bargain over the extent of agent autonomy. The principal(s) prefer that the agent will use its autonomy to further their interests, but 'agency loss' —when the preferences of the agent diverge from those of the principal-is inevitable due to information asymmetries and fundamentally different underlying interests (Hawkins and 
Jacoby 2006; Vaubel 2006). Bureaucratic agents possess greater information than principals and are not subject to electoral pressures - which many, if not all, national governments must face. Furthermore, bureaucratic agents (here RDB boards of directors) are frequently driven by underlying interests that involve resource expansion: "more staff, a larger budget and increasing competencies' (Vaubel 2006: 127). For these reasons-asymmetric information and different underlying interests - agents (here RDB boards of directors) are prone to develop different preferences from the principal. 'Agency losses' - that is, shirking, slippage or even sabotage — occur. 'Shirking' refers to the agent failing to act in a manner that best serves the interests / preferences of the principal, i.e., putting no effort into fulfilling the delegated task or less effort than necessary, concentrating instead on promoting its own interests; 'slippage' involves the agent following its own preferences which diverge from those of its principal(s); while 'sabotage' involves the agent acting in outright conflict with the principal's preferences and underlying interests (Bendor et al. 2001). The principal can adopt a range of ex ante and ex post mechanisms through which to control the agent (McCubbins and Schwartz 1984). Moreover, the preferences of the principal might shift over time - away from the terms of delegation — due to a number of factors, including new members. In detecting the form of 'agency loss' it is crucial to take into consideration a possible shift in the principal's preferences and the danger of 'observational equivalence' (Weingast and Moran 1983).

The preferences of the RDB agent to what we refer to as the five functions of regional development banking-development, regional integration, market promotion, multipolarity reinforcement and interventionist market shaping, including industrial policy—may come to differ from that of its multiple principal. Given the RDB's day-to-day focus on core lending activities, we can draw the hypothesis that the RDB agent would tend to engage in 'slippage' and prioritise development and, notably, market promotion over the more 
political goal of regional integration which is specifically noted in all RDB articles of agreement. The RDB agent continued to pursue regional integration and, more recently, geo-political ambitions involving multi-polarity, but only as secondary goals to development, market promotion and, most recently market shaping. We have evidence of most of the RDB studied in this volume having demonstrated agency in attempting to expand their resources, as predicted in Principal-Agent analysis. Furthermore, we argue that most RDB have made deliberate use of their advantages in information and expertise in relation to their national government principals, to shift the main de facto goals and activities of RDB. Thus, RDB officials have played a central role in the shift from Continental and Sub-regional-integration RDB to Continental market-led and Sub-regional market-ledintegration $\mathrm{RDB}$, and then to +Continental strategic market and +Sub-regional strategic market integration RDB. The multiple principal - the board of governors / national government shareholders - could have made use of ex ante and ex post control mechanisms to rein in the RDB agent and prevent slippage. However, we see few examples of national governments blocking RDB activities to promote markets during the second period of RDB development or engage in more interventionist market shaping.

\section{The regional development banks}

In this section, we provide an overview of the establishment and evolution of the major $\mathrm{RDB}$ in the world economy from the post war period to the present with insights from an application of the Principal-Agent approach. Here we develop upon the five main RDB functions and how these have shifted over time: development, regional integration, market construction and multi-polarity reinforcement.

The World Bank: a precursor of RDB? 
Our comparative analysis of RDB takes as its point of departure the establishment of the world's first global MDB, the International Bank for Reconstruction and Development (IBRD) or the World Bank, created in 1944. Most studies locate the institutional origins of the main Continental and Sub-regional-integration RDB in the IBRD. In particular, a number of authors argue that the RDB created in the years after the IBRD were influenced by its statutes, mandates, policy objectives, operations, technical assistance and policy advice at the regional level—see, for example, Singh (1969), White (1970 and 1972), Culpepper (1994), and Rhagavan (2016).

The apparent 'global' scope of the IBRD as its name would suggest hides at least two important motivations in the logic behind its creation: reconstruction in Europe and development in Latin America. With regard to European reconstruction, Hans Singer (1995) demonstrated that the IBRD, in fact, had a European rather than universal scope, at least during its early years of operation. ${ }^{3}$ With regards to the Americas, the first proposal to create a Continental RDB for the Americas dates back to the 1890s and had been presented at the First Pan-American Conference. In fact, the IBRD had been inspired by a US proposal for a Continental RDB for the Americas, the Inter-American Bank (IAB). Following the outbreak of the Second World War in 1939, the Roosevelt Administration returned to work on an earlier proposal on the IAB for presentation to Congress. Oliver (1971) describes how Dexter White-the American architect of the Bretton Woods institutions - had been inspired directly by the draft proposal of the IAB in his contribution to

\footnotetext{
${ }^{3}$ Singer (1995) describes how the IBRD was originally conceived by American and British policy-makers as an RDB for Western Europe before the outbreak of the Second World War, as an alternative mechanism to bring about European economic development to counter Walter Frank's ambitions through the Nazi's 'New Order' plan.
} 
plans on the IBRD. ${ }^{4}$ In sum, the institutional model for the IBRD did not emerge from plans to address the global objectives of reconstruction and development (Helleiner 2017). Rather, it was borne of longstanding discussions, ideas and projects designed for RDB to deal with political and economic challenges, in particular, in Europe and the Americas.

However, in the immediate post-war period, the reconstruction and relief tasks of the IBRD for Europe became less important, due to the introduction of the European Recovery Plan (Marshall Plan 1947-1951) and the establishment of the Organisation of European Economic Cooperation (OEEC), which had been selected to disburse US aid to Western European countries (Clifton and Díaz-Fuentes 2011). As tensions increased between the USSR and the Western powers, and the shadow of the Cold War deepened, the central aim of the Marshall Plan and the OEEC was to promote strong market economies as an alternative to the command or planned economies led by the USSR. In this context, the IBRD assumed global development as its main function-which at the Bretton Woods conference had been pursued by Latin American and Caribbean countries, and which would be supported by an increasing number of newly independent countries in Africa, Asia and the Pacific Rim. Under the presidency of Eugene Black (1949-1963), the IBRD operated as a semi-autonomous agent. With close ties to the Wall Street financial elite-Black had previously been Vice-President of the Chase Manhattan Bank - the president and the bank's Board of Directors, oriented the World Bank Group mainly to productive investment projects (inter alia, dams, power stations, and railroads) to promote economic development and market construction in market economies (Alacevich 2008, 2009). Thus, the world's first development bank set the precedent for MDB and RDB agency.

${ }^{4}$ Although the IAB never materialised, it did, nonetheless, provide a blueprint which shaped later discussions on the creation of the IBRD. 
Though the IBRD assumed its global role as a world development bank, the challenges of each continent and region were significantly different. Member states, therefore, as well as newly emerging countries post-independence, argued that the creation of RDB would be the best way to address the specific needs of each continent and region (White 1972, Culpepper 1994, Griffith Jones 2008). When subsequent RDB were created, both Continental and Sub-regional variants, both adopted key elements of the World Bank's statutes, mandates, policy objectives and governance institutions, but adapted them to regional-specific challenges and the needs of their members.

\section{Creating Continental and Sub-regional-integration RDB}

The model of the IBRD - an international government-owned institution with statutes, mandates and objectives to invest in development projects, particularly infrastructure, under favourable long-term conditions, including low interest rates-was transferred directly into the design of three RDB which prioritised the development of the continent, or continents in which they were established: the IADB, established in 1959; the AfDB, in 1964; and the ADB, in 1966. These RDB resembled the IBRD in many respects, including its mandates and approach to financial cooperation. These banks were established to provide specific forms of multilateral funding, technical assistance and policy advice to less-developed member countries in their respective continents.

Despite sharing several common basic features, these three RDB were different in a number of important respects. First, they differed in terms of the heterogeneity of member country as regards economic, political, cultural, institutional and social characteristics. On a 
continuum, the IADB was the most homogenous RDB in linguistic and socio-political terms. In contrast, the AfDB was the bank with the greatest heterogeneity among member states, bringing together as it did newly independent countries, which were constituted by distinct groups based on colonial inheritance and official language. In addition, representatives of soon-to-be independent colonies worked towards the project of creating the AfDB. Hence, the dynamics of the internal relationships among members in the governance of these three RDB differed sharply. Second, the ways in which shareholding power was distributed differed. From the outset, the US was the largest shareholder of the IADB, which meant it could influence the Bank's policy across the Americas. Along with Japan, the US was also the largest non-borrowing shareholder in the ADB. In contrast, the USlike other countries outwith the African continent—was originally excluded from holding shares in the AfDB. It was only from 1982 onwards that the US emerged as the major shareholder of the AfDB Group.

The IADB can be considered an RDB that reflects the manifestation of US financial hegemonic power across the Americas and the Caribbean. Among the 44 states that attended the Bretton Woods conference - a main purpose of which was to establish the IBRD in 1944 - there were 20 Latin American and Caribbean countries that demanded that the IBRD prioritise active financing for their development and not just relief and reconstruction for Europe (Helleiner 2017). Once the UN system was established, with its original 51 member states, its Latin American and Caribbean members proposed the creation of a sub-regional body, the Economic Commission for Latin America and the Caribbean (UN-ECLAC), in order to promote industrialisation and infrastructure projects for development in the region. From the outset, the US and Canada were opposed to establishing the UN-ECLAC, fearing they could be excluded, and because they wanted to be part of a continental Inter-American organisation (as they had been in the Inter-American Treaty of Reciprocal Assistance, 
signed in 1947, and the Organization of American States, founded in 1948). The original opposition to the UN-ECLAC was not only from the US but also from the USSR, the United Kingdom and France. Despite this, one year later, in 1948, the UN-ECLAC was established with a broad UN agreement and with the membership of all Latin American and Caribbean countries, plus the United States, Canada, France, the Netherlands, and the United Kingdom. Thus, a decade before the IADB was established, in 1959, the UN-ECLAC members had already set up an integrated institutional framework through which industrial and infrastructural projects for development could be conceived and funded. Additionally, the need for an RDB focused on Latin America had been called for from 1948 by the UNECLAC, on the grounds that the IBRD did not pay sufficient attention to the development of their continent. The IADB was finally established in 1958, with the support of the US and Canada. The US would be its main, non-borrowing and dominant shareholder, even though the Latin American and the Caribbean members collectively enjoyed a majority of voting power. As argued by Pablo López and Marcelo Rougier (this volume), as the IADB evolved, its relationship with national development banks (NDB) began to weaken and, during the 1990s, its loans became increasingly conditioned by market criteria, including the implementation of market-oriented policies in line with the Washington Consensus.

By the end of the 1950s, the economic and political situation in Africa was very different to that in Latin America. Most African countries were still colonies or occupied territories that were struggling for independence from European colonial powers. At the Conference of the Peoples for Africa held in 1960, a resolution was approved to create an IFI on a continental scale. The agreement for a RDB was prepared and signed by the governments of 22 new African states in 1963 at the Conference of African Ministers of Finance in Khartoum, Sudan (AAI 2015). Thus, when the AfDB began operating in 1964, its member countries had experienced less than a decade of independence, whilst colonies still on route to independence 
were represented by provisional authorities. Given ongoing divisions rooted in different colonial legacies and new divisions derived from different approaches to development, AfDB member state governments failed to agree upon a clear common strategy for continental development. The strong cultural, linguistic and regional differences were reflected within the management and shareholding structure of the AfDB. Shareholders' voting patterns tended to align with a myriad of cultural, geographical and linguistic blocks, including francophone, anglophone, northern, eastern, central, western and, later, south African blocks. The failure to develop a clear common strategy can also be blamed on the UN-Economic Commission for Africa (ECA), which had been established in 1958, following the establishment of the UN-Economic Commission for Asia and the Far East (ECAFE) in 1947 and the Latin American version, UN-ECLAC, in 1948. The ECA was largely focused upon the basic needs of building national economic and social institutions under conditions of conflict and extreme poverty. Moreover, newly independent African governments baulked at the imposition of financial conditionality from donor countries outside of their continent — and non-African control, particularly if they were former colonial powers, but also the US and the USSR. Thus, initial AfDB capital was subscribed exclusively by newly independent African countries, excluding the participation of nonAfrican countries (Schiavone 1997). Indeed, as Erika Kraemer (this volume) observes, the AfDB's national shareholders intended to preserve African ownership and identity. However, given the immense economic and social deprivations of the continent, as well as the financial restrictions imposed by its initial capital governance reserved exclusively for continental members, the AfDB Board of Executive Directors demonstrated agency by pushing actively to extend membership to wealthier countries outwith Africa (see Kraemer this volume). In 1972, AfDB member state governments agreed to create an African Development Fund (AfDF) which would be open to countries beyond the continent as donors. The objective of the AfDF was to finance, on concessional terms, the poorest 
African countries. Despite this, there remained a lack of resources from which to draw. Hence, in 1982 - following years of active recommendation from the AfDB itself - the AfDB member state governments finally allowed countries beyond the continent, including the US, to join as non-borrowing shareholders, albeit with a much smaller subscribed capital and voting power than in the IADB and ADB. Officially-if not in practice-non-African shareholders were permitted as long as the Bank preserved its 'African character'. In her chapter for this volume, Kraemer offers an important contribution exploring the historical evolution of the AfDB with regard to its efforts to tackle key issues related to industrial diversification, the protection of the natural environment, inclusion and innovation, and the extent to which the bank is effectively positioned to develop present and future 'African solutions to African challenges'.

In the case of Asia, during the 1950s, the problems in the region were similar to those in the African continent, though on a much larger scale, as the region represented more than half of the world's population. Following the Second World War and, in the context of decolonisation and the spread of communism, Asia witnessed some of the worst conflicts of the Cold War period. However, with regard to the international economic and financial institutions for development, there were more similarities between Asia and Latin America than with Africa. In 1947, the UN approved the creation the Economic Commission for Asia and the Far East (UN-ECAFE which was renamed UN-ESCAP in 1974). Originally, the UNECAFE had been established for post-war relief and reconstruction, the reduction of extreme poverty and postcolonial institution building. In the 1960s, the UN-ECAFE played an important role in the definition of the main lines of regional development and financial cooperation. The Vietnam War, like the Cuban Revolution in 1959 in Latin America, made it imperative for the US government to increase its involvement in Asia, in particular, with a view to prevent the spread of communism (through its policy of containment). Hence, the 
US administration supported the creation of the ADB in 1965 to support the spread of capitalism and financial cooperation across the continent. From its establishment, the ADB's shareholder structure and the distribution of votes to countries from beyond the continent were more open than the AfDB and, even, the IADB. Some nineteen of its original members were from Asia and the Pacific, whilst twelve were countries outside of Asia. However, whilst the IADB included the majority of Latin American and Caribbean countries, the ADB had a more limited geographical scale, with the absence of non-capitalist countries - such as the Peoples' Republic of China until 1986 - and Iran and Russia-which are still nonmembers to the present day (see Lanthier and Barjot, this volume).

Hence, the ways in which each of the RDB's shareholder governance was established in the initial period differed significantly. The involvement of the US was greater in the Latin American and Asian RDB than in the African case. The US enhanced its involvement in the IADB and the ADB as part of its response to the Cuban revolution and the Vietnam War, whilst, in the African case, foreign involvement was perceived with suspicion by the AfDB's member state governments and initially rejected.

Just as the IBRD model was adapted into the three RDB working across continents, so it was also translated into those RDB that prioritised sub-regional integration. The most important of these RDB were in Europe - the EIB, founded in 1958 - and in the Americas, CABEI, established in 1960, and the CAF, set up in 1968. The Soviet Union established a bank for the COMECON countries - the International Bank of Economic Cooperation (IBEC)—which also presented itself as a bank promoting integration. However, this bank was a short-lived and, ultimately, flawed attempt to integrate the command economies of Central and Eastern Europe. 
The first RDB for integration emerged as part of the European Economic Community (EEC): the EIB, founded in 1958, was known as the 'Community's Bank'. After the Second World War, a project for uniting Western European countries gained support, with the aim of maintaining peace, containing Soviet influence, and strengthening national economies by opening them to increased competition and economies of scale of markets. The EIB became, then, the main precedent for the establishment of a regional bank in charge of promoting the economic development and integration of its members. The creation of the EIB reflected above all Italian and French demands for financial support to compensate for their comparatively weak competitiveness and underdeveloped regions and sectors (Bussière et al. 2008). Later, the possibility of EIB finance to reduce regional disparities served to attract other European countries to join the EEC / European Union (EU) (Clifton et al. 2018). EIB finance thus became an important symbolic and practical element of the integration process (see Clifton et al., this volume).

In 1960, CABEI was set up for the Central American Common Market (CACM). Over the next six decades, the CACM has proved to be surprisingly stable despite the considerable political and economic upheavals in Central American and one of the most stable regional integration areas in the Global South. In parallel to the establishment of the EEC and the EIB, policy-makers in Central America became increasingly strong advocates for closer regional economic integration, particularly from the late 1950s until the 1970s. Both the EEC and the EIB directly inspired Central American leaders who signed the General Treaty on Central America Economic Integration, which included the establishment of CABEI (García 2015). Moreover, during the 1960s, a number of Central American leaders also undertook efforts to establish a monetary union, but the project lacked broad political support and institutional capacity (Desruelle and Schipke 2008). José Efraín Deras, ${ }^{5}$ Alberto 
Cortés, and Guillermo Funes (this volume) examine the contribution by CABEI to economic and social development and regional integration. CABEI changed its focus from an original 'closed regional' approach to a more 'open regional' approach during the 1990s. However, the overwhelming bulk of its activities remained focused on the region itself. At the same time, CABEI engaged in agency slippage to re-orient its lending activities towards the private sector and to attract private international investors, though this activity was rather modest (see Deras et al., this volume).

In the late 1960s, a second Integration RDB was established in Latin America, this time, composed of the members of the Andean Group (Bolivia, Chile, Colombia, Ecuador, Peru and, later, Venezuela). CAF emerged as an instrument to foster the economic and political integration of the Andean Group. Carlos Brando (this volume) demonstrates how CAFunlike the IADB and the IBRD but like the AfDB — was founded as a RDB by developing countries, intending to lend to other developing countries. In other words, the Corporation was developed 'by the poor, from the poor, and to the poor' (Brando, this volume: XX). CAF has been successful without being dependent on external powers, in particular, the US. The Corporation began operation in June 1970 to promote regional integration and development. Despite the fact that the Andean Group did not progress as had been originally envisaged, and some of its founding member states abandoned the sub-regional integration process in subsequent decades (Chile in 1976 and Venezuela in 2006), CAF maintained all the original shareholders and went on to expand its sub-regional membership. Brando argues that $\mathrm{CAF}$ has been successful in allocating voice to some of its smaller members, such as Bolivia and Ecuador, as well as performing in line with its original mandates and constitutive principles. However, Brando also shows how, from the 1990s onwards, CAF 
demonstrated agency by expanding its activities beyond the integration focus of its original five Andean country shareholders, focusing instead principally upon development and market making activities, leading to it becoming Latin America's largest development bank.

While most RDB were established in market economies, the command economies also attempted to promote their own IFI and RDB. Though the USSR, Poland and Czechoslovakia participated in the Bretton Woods conference in 1944, they refused to take part in the IBRD (World Bank) and IMF, which they labelled instruments of imperialism and colonialism (Schröder 1982). In 1949, the USSR established the Council for Mutual Economic Assistance (COMECON) with six East European countries (Bulgaria, Czechoslovakia, Hungary, Poland and Romania). One of COMECON's founding objectives was to create alternative IFI to the IMF and IBRD with the aim of facilitating international trade and to better integrate the infrastructure among its members. However, it would take more than a decade, in the shadow of the Cold War in 1963, for the International Bank of Economic Cooperation (IBEC)— the Soviet Bank—to be established (Bednarik 1966). The IBEC was mainly an instrument of Soviet domination of the COMECON command economies. However, shortly after its creation, the IBEC expanded geographically beyond Central and East Europe to integrate other command economies in Far Eastern Asia and the Caribbean (Mongolia 1963, Cuba 1974 and Vietnam 1977). With the collapse of the USSR in 1991, the IBEC phased out its financial and trade functions (based on transferable roubles) and accounting activities (Conway 1995).

Regional Development Banks and the turn to the Market

As we have seen, the RDB established in the 1950s and 1960s focused upon continental development and sub-regional integration, and operated in capitalist economies - with the 
exception of the IBEC. In the aftermath of the Cold War and, with the collapse of most of the command economies, there was renewed attention to market promotion. This period saw the emergence of new RDB, which were characterized by different priorities to those established in the 1950s and 1960s. At the same time, those already-existing RDB from the first period underwent a shift towards market promotion-which we explain in large part in terms of RDB agency—albeit to differing degrees.

After the command economies collapsed, a new challenge emerged in Europe. Central and Eastern European countries were faced with huge financial needs, which most of the EEC member states were keen to meet with a view to helping these countries transition towards market economies. The idea, promoted by French President François Mitterrand, to create a new RDB, gained strength. While the EIB would focus on the EEC member states, a newly proposed institution would work in parallel to and complement the EIB, and focus on supporting the transition of Central and Eastern Europe towards market economies.

The European Bank for Reconstruction and Development (EBRD) was set up in 1991 with 40 national shareholders. The EBRD was not just a new RDB for economic and political transition in the former communist countries. It was also representative of a change in the approach, objectives and functions of other RDB. The EBRD was established at a rapid speed on 29 May 1990 and was operational less than a year after, in contrast to other RDB which took years or decades to be established. The new bank was an important source of transition knowledge and expertise for Central and Eastern Europe, and beyond, and was to guide these countries towards an open-market economy (see Shields, this volume). EBRD economists Willem Hendrik Buiter and Steven Fries (2002) disagreed with the traditional view that RDB and global MDB should be fiscal agencies for the allocation of grants either to ensure international redistribution or to finance international public goods. 
Rather, they asserted that the EBRD and other RDB should foster market reform by investing primarily in privatisation. Shields (this volume) argues that the EBRD is something of an anomaly among $\mathrm{RDB}$, to the extent it is officially a development bank but actually resembles a merchant bank, due to its use of commercial criteria, its focus on private sector development, and the manner in which it produces knowledge, with the aim of promoting competitiveness, and the establishment of 'correct institutions'. Steven Roper (this volume) compares the design of EBRD to that of IADB, both established in regions undergoing dramatic economic and political change-Central and Eastern Europe from the 1990s after the collapse of Communism in that region and Latin America in the shadow of the Cold War in 1959. Finding their structures to be quite similar, but their mandates quite different, Roper argues that the reason the IADB has been able to focus on social development and poverty reduction loans, whilst the EBRD has concentrated on private sector development can be largely explained by the fact the IADB has ultimately been controlled by its borrowers, whereas the EBRD has been controlled by its lenders.

In the political and intellectual climate of the 1980s, many of the existing RDB shifted towards a more market-oriented focus. A re-orientation towards the market economy was also developing within the global MDB, notably within the World Bank and the IMF. A key event in this period was the debt crisis that hit Latin America and Africa particularly hard. The shift to market promotion can be seen very clearly in the case of the IADB. Sarah Babb (this volume) uses newly declassified documents from the US National Archive as well as information retrieved through the Freedom of Information Act to explore how the IADB was gradually subjected to greater control by the US at the expense of influence from Latin American countries during the 1980s. In 1982, though the IADB operated under a Latin American majority, with the US holding only 34.6 per cent of the votes, the Bank became the target of the Reagan Administration's policy to reduce the 
scope of public intervention by both domestic and international institutions. When Mexico and Brazil declared a foreign debt moratoriumin 1982, the US Treasury made US participation in $\mathrm{RDB}$ and global $\mathrm{MDB}$ conditional upon policy reforms, stating that borrowing countries would be 'graduated' (non-eligible for loans) once they reached a certain level of GDP per capita and met thresholds of reliance on private finance (ODI 1991). Babb (this volume) argues that, through the Baker Plan (1985), a decision was taken to attach conditionality strictly to loans to Latin America. Specifically, the Reagan Administration imposed market-oriented policies upon Latin America governments seeking to benefit from IADB lending. The IADB was placed under supervision of the World Bank and became the third financial institution to push so-called Washington Consensus policies, after the World Bank and the IMF. The Reagan Administration also insisted that lending programmes should promote privatisation, trade, investment liberalisation and neoliberal economic policy reforms (Lustig 1997). Gradually, the IADB moved from a traditional project loan approach to a conditionality approach based on adjustment loans which were regularly associated with austerity measures similar to those imposed at the time by the World Bank and the IMF (Babb, this volume). Thus, in the case of the IADB, it would be problematic to assign a decisive role to RDB agency in the move to market construction. Clearly, senior IADB officials may have supported the transformation of Bank lending policies. However, the role of US administration pressure was crucial.

Similar pressures in favour of market promotion and a more programme-based lending were experienced by the ADB and the AfDB (ODI 1992). By the 1990s, those RDB that had originally focused on development of the continent had experienced a shift away from a development approach towards the promotion of structural adjustment as advocated by US administrations and inscribed in the so-called Washington Consensus (ODI 1996; 
Rana et al. 2014). However, while this development reflected pressure from the US government shareholder, our chapter authors also argue that the ADB and AfDB demonstrated considerable agency in pushing the new approach to lending (Barjot and Lanthier, this volume; Kraemer, this volume).

In the EEC/EU, the EIB had long played a role in promoting both market integration and liberalisation. Clifton et al. (2017) examine EIB lending from the 1960s to the 2000s demonstrating a move away from the EIB's initial focus upon reducing regional and national disparities in the EEC/EU to lending that was proportional to shareholding. In their chapter for this volume, Howarth and Liebe argue that the EIB promoted market / private sector solutions to public funding needs—-specifically Public-Private Partnerships (PPPs) - from the late 1980s. In this, the EIB was only the first of most of the RDB to engage in the promotion of market forces. The EIB was able to direct a massive policy network on PPPs reaching across European Commission directorates-general, down to national, regional and local authorities, and to private sector operators (both financial and infrastructural companies). The EIB initially promoted PPPs through major EU transport, energy and communication infrastructure projects - the Trans-European Networks (TENS). From 1998, the EIB began to discuss the usefulness of PPPs in its monthly newsletters (EIB 1998). The EIB promoted PPPs at both EU and national levels as potentially being more efficient than alternative mechanisms of public financing, with lower maintenance costs, better risk management, better quality, and faster implementation. The EIB also raised the possibility of PPPs when it focused upon investment in less developed areas and accession countries. The EIB's efforts were bolstered from 2008 by the creation of the European PPP Expertise Centre (EPEC) within the Bank, with the official mandate of capacity-building among participating member states and as a forum for information exchange among members. By early 2020, EPEC 
had 31 national units as members and an addition eight sub-national (regional) units. EPEC was thus explicitly created with the aim of helping to strengthen the capacity of its national public sector members to enter into PPP transactions. Furthermore, the EU Commission and Council agreed upon the requirement that all countries seeking EIB funding were obliged to establish PPP units. The EIB was regularly present when PPPs were discussed at the European level, with the aim of preparing and facilitating a 'window of opportunity' which — while opened an inch or two for a couple of decades—was fully opened in the years following the outbreak of the international financial crisis (from 2008) and then euro area sovereign debt crisis (from 2010). Through this activism, the EIB agent engaged in agency slippage, going well-beyond its mandate set by its shareholder principals and promoting a financing mechanism that a number of member states had previously discouraged at the national level. Howarth and Liebe (this volume) also point to the rapid growth in PPP promotion and usage by almost all RDB throughout the world. This promotion and usage has been encouraged through co-financing and expertise from the World Bank Group and the EIB, and by the British government through its development aid.

Regional Development Banks, Shifting Wealth and the return of the 'policy that should not be named'

The third and most recent period of RDB creation occurred in parallel to the economic and geo-political rise or re-emergence of countries in the South and East. Though this shift is largely a consequence of the re-emergence of a global economic power-the PRC - it is also associated with the gradual relative decline of traditional Western economic powers and the faster growth in a number of newly emerging economies, including Brazil, India, 
Indonesia, Mexico and Russia. Alice Amsden (2001) predicted early on that, by following specific policy approaches, notably forms of state intervention in industrial policy, the 'rest' could attempt to catch-up with the West, resulting in an increasingly 'multipolar' world economy (Clifton et al. 2016). Kishore (2013) argues that the rise of these new players from the Global South will lead to strategies whereby existing institutions-here, the global MDB and RDB - are increasingly challenged by countries in the Global South, after experiencing them as insufficiently flexible and attentive to their needs and demands.

There are two main shifts in this third period of RDB creation, one affecting the geography of RDB, the other, their function. Starting with geography, both the new and already existing RDB — as well as the new and existing national development banks (NDB) — adopt a broader and more ambitious vision of the geography in which they can operate (Mazzucato and Penna 2016; Mertens and Thiemann 2019; Griffith-Jones and Ocampo 2018). Newly established NDB, such as the China Development Bank in 1994, and the redeveloped NDB in Brazil (BNDES) in the first decade of the 2000s, provide examples of development banks that operate beyond their national space. These NDB have also designed the New Development Bank (the Bank of the BRICS) as a global MDB, as opposed to an RDB (Humphrey 2016; Wang 2017; Wang 2019). Both the AIIB and the New Development Bank offer an increasingly important source of alternative finance than that provided by the existing RDB.

With regard to the function of RDB, there has recently been an important—albeit unevenshift in the form of renewed attention to a role for industrial policy. The traditional function of RDB was to leverage public funds, acting as catalysers for entrepreneurial and innovative investment when capital was scarce, whilst also playing a countercyclical role, providing access to capital during economic downturns, when private investors were 
reluctant to invest. Recently, however, RDB have entered into new funding areas, including new technologies and the global green economy (Griffith-Jones and Cozzi 2017). RDB (as well as NDB) are increasingly adopting - or being urged to adopt - a longer-term perspective, in order to cope with the risks associated with the funding of innovation.

This shift in function can be understood as a rebalancing of the trend towards the market, as discussed with regard to the second period of RDB creation, and is part of a global trend. IMF Chief Economists have expressed support of the re-emergence of industrial policythe 'policy that shall not be named' (Cherif and Hasanov 2019a and 2019b). The attitude to industrial policy differs markedly by region. Whereas in Asia, industrial policy has largely remained a legitimate one throughout the post-war period (Wang 2017), in Europe - where it went out of fashion in the 1980s - there is a revival (Mertens and Thieman 2018; Mertens, Thieman and Volberding 2019; Naqvi, Henow and Chang 2019).

The AIIB is the harbinger of new RDB created in the context of Shifting Wealth. This bank was set up in 2014 with the stated aim of covering the infrastructure financing gap in developing countries worldwide, and developing Asia in particular. Jianjun $\mathrm{Xu}$ (this volume) argues that the creation of the AIIB reflects nothing less than the rising challenge by China to US hegemony. China has adopted a 'two-legged' approach (Xu, this volume): it has continued to vie for power within the already existing MDB but, at the same time, has focused on the creation of new development banks at the international, regional and national levels. In the absence of sufficient international political will to change the voting power within existing multilateral and regional institutions - for example, as chronicled by Wade (2013) at the World Bank-China decided to act. The AIIB was established with a capital of USD 100 billion and 57 founding member countries, which increased to 77 prior to the start of AIIB operations in 2016. Xu explores how the design of AIIB governance, membership, capital 
stock, financial instruments, mandates and lending practice reflect these shifts, comparing this new bank to the World Bank and the ADB in particular. For example, with regard to RDB voting power, whilst in the ADB, Japan and the US together can potentially veto a decision, in the AIIB, the PRC alone holds this power. The AIIB's reach goes far beyond the continent in which it is based: rather, geography seems irrelevant, as the bank seeks out countries with an interest in and need for its 'shared vision'. Therefore, rather than pursing traditional regional integration, the AIIB officially seeks to promote lending and borrowing well beyond the region. In the space of a few years, most of the world's largest economies have become shareholders, with the notable exceptions of the United States and Japan, which continue to prioritise the role of the ADB in Asia and the Pacific.

In addition, previously established RDB have become more ambitious as to their reach. In Latin America, the CAF is an important example, having extended its lending activities beyond the Andean Group. From the middle of the 2000s, the CAF expanded to include additional and larger members, and notably Argentina and Brazil. This expansion allowed the bank to access increased capital and offer more loans with lower conditionality restrictions than applied by other RDB in Latin America, including the World Bank and the IADB (Babb, this volume). This has made CAF a particularly attractive source of funding for Latin American countries. In 2005, the founding statute of CAF was modified to allow non-founding members (Argentina, Brazil, Panama, Paraguay, Uruguay and Trinidad and Tobago) to become full members. The bank was renamed the 'CAF Development Bank of Latin America'. This was not just a simple rebranding exercise but indicative of an explicit ambition to become the largest Latin American RDB in the 2010s (Brando, this volume; CAF 2016).

The AfDB has demonstrated both tendencies of the third period (see Kraemer, this 
volume). First, it has continued to expand its membership beyond the African continent, a process started in the early 1980s. Of the AfDB's 80 member states, 26 today come from outwith the continent. To counter US and European influence, the AfDB Group accepted both Indian and Chinese government membership as early as 1982 and 1985, respectively. The importance of joint initiatives with the PRC have increased considerably over the past two decades and China has become the thirteenth largest contributor to the AfDF. ${ }^{6}$ Second, the AfDB has recently embraced a return to a more interventionist market shaping policy, notably through the Bank's 'High 5s' development priorities adopted in 2016 (AfDB Group 2019). The 'High 5s' include energy production and supply, and agricultural infrastructural projects but also a priority focused upon industrialisation (see Kramer, this volume). This interventionism has come hand in hand with a renewed focus on economic integration in the continent.

In Europe, too, RDB are adapting. The EIB is a good case in point. In the aftermath of the Great Recession of the late 2000s and early 2010s, the EIB came under criticism for overly conservative lending patterns and for failing to meet long-term development goals in the region and beyond (Clifton et al., this volume). In 2015, the European Commission advocated a 'promotional role' for the EIB in supporting the Commission's Investment Plan for Europe and European Fund for Strategic Investment (European Commission 2015; Kavvadia, this volume). Moreover, there is some evidence of the EIB performing the role of an activist agent by pushing in favour of interventionist market shaping. For example, the EIB president, Werner Hoyer, claims that he conceived the Investment Plan for Europe and promoted it to the Commission (Hoyer 2015). Simultaneously, several European countries have established new 'promotional' NDB (European Commission 2015, European Parliament 2016). Examples are the British Business Bank (2014) and the Green Investment

${ }^{6} \mathrm{https}$ //Www.afdb.org/en/countries/non-regional-member-countries/china 
Bank (2012) in the UK, the Strategic Banking Corporation (2014) in Ireland, and the Instituição Financeira de Desenvolvimento (2014) in Portugal. Moreover, existing NDB, such as the German KfW (Kreditanstalt für Wiederaufbau) and the Spanish ICO (Instituto de Crédito Oficial: Oficial Credit Institute) have renewed their development functions to respond to the EU's investment plans (Mertens et al. 2019; Clifton et al. 2019). Over the past decade, for example, the EIB has become a world leader in the promotion of green bonds. Moreover, in 2019, the High-Level Group of Wise Persons argued that the EIB and EBRD required urgent restructuring to avoid inefficiencies and duplications, with a view to bolster a strong development global action plan beyond Europe, particularly, in view of the challenges in Africa and as a result of climate change (Wieser, et al., 2019; Kavvadia, this volume).

\section{Conclusion}

In this chapter, we offer a revised categorisation of RDB, through an analysis of their changing geographical operations and their changing prioritisation of five functionsdevelopment, regional integration, market promotion, multi-polarity reinforcement and strategic market shaping/industrial policy_over three periods. We argue that most RDB moved from a prioritisation of regional development and integration towards a prioritisation of regional development and market promotion and then to a prioritisation of geographic expansion and, for a few RDB, multi-polarity and strategic market interventionism and, for a few RDB industrial policy. We also argue that in the TwentyFirst Century at least one RDB - the AIIB - one MDB and a number of NDB have been created to promote multi-polarity in the world. Over the past two decades, a number of older RDB have extended their activities geographically beyond their original area of operation - be it a continent or a sub-region. Furthermore, we detect the reassertion by a 
number of RDB of an industrial policy designed to promote regional development. The RDB that were created in the 1950s and 1960s were categorised by White $(1970,1972)$ as Continental and Sub-regional-integration' RDB. These transformed into what we label Continent Market-Led and Sub-Regional Market-led Integration RDB in the second period and, in the third period, to +Continental strategic market' and +Sub-regional strategic market integration RDB.

To explain these transformations, we argue that most RDB have operated as semiautonomous agents engaged in 'slippage'. Most of the RDB that we examine in this volume developed preferences on their activities that diverged from their multiple principal - their member state government shareholders-because of different underlying interests and information asymmetries. During the second period, all of the existing RDB sought to prioritise market-led policies: hence, RDB such as EIB that promoted integration focuses on 'market promotion', whilst Continental RDB pushed a market-led development (Caroll et al 2019). During the third period, a number of RDB sought to increase the geographical spread of their membership and lending patterns, while engaging in more interventionist market shaping activities. There is clear evidence that the AfDB, CAF and the EIB all having pushed their member state shareholders in this direction. Vaubel's claims (2006: 127) regarding World Bank interests - that it sought 'more staff, a larger budget and increasing competencies'-were paralleled in the efforts of most RDB similarly focused on resource expansion. During the third ongoing period, if we are to witness the development of an increasingly interventionist RDB industrial policy, this would also likely reflect semi-autonomous agency and these underlying interests. Having made this argument in favour of the usefulness of the Principal-Agent analysis to explain the development of RDB activities over the past sixty years, it is nonetheless important to recognize the limits to the explanatory merits of this approach. RDB agency was 
constrained in a number of cases - notably where member state shareholders asserted political objectives. RDB agency was also constrained in cases-notably the IADB and the ADB — where a powerful element of the principal—respectively, the US government and the Japanese government - actively shaped the development of the RDB in favour of market promotion during the second period. However, in these two cases, US and Japanese government preferences on the prioritization of market promotion broadly aligned with the preferences of most RDB at the time.

In their concluding chapter to this volume, José Antonio Alonso and José Cuesta ask if 'we still need Regional Development Banks today (and tomorrow)?' Although they avoid a conclusive answer to this question, they nonetheless point to the important position of RDB in the global economy. In addition to tackling market failure - and specifically overcoming the unwillingness of private sector finance to invest in long-term and costly infrastructural projects in many parts of the world-RDB are particularly well-placed to overcome collective action problems related to the provision of regional public goods (RPGs), given the complexity and the supranational scope of these kinds of goods. Bridging huge gaps in infrastructure financing is crucial for development in many parts of the world. Furthermore, in the context of slower global economic growth, investment in infrastructure offers a strategy for immediate growth but also a way to invest in climate friendly technology that promotes environmentally sustainable growth. The recent creation of the AIIB indicates both the frustration of the Chinese government with existing RDB and its recognition of the ongoing relevance of $\mathrm{RDB}$. At the same time, the AIIB creates a potential challenge as an innovative RDB. Its emergence combined with the rising profile of a number of RDB (such as the CAF Latin American Development Bank) provide traditional RDBs with possible guidance to reform their organisation, administrative procedures, infrastructure investment and even policy remit. 


\section{REFERENCES}

AAI (The Africa-America Institute) (2015). From the Archives: Establishment of the African Development Bank, 15 April. Available online at: http://www.aaionline.org/from-the-archives-establishment-of-the-african-developmentbank/. Accessed 25 January 2018.

Alacevich, M. (2008). The World Bank's early reflections on development: a development institution or a bank? Washington: The World Bank.

Alacevich, M. (2009). 'The World Bank's early reflections on development: a development institution or a bank?'. Review of Political Economy, 21(2): 227-244.

Babb, S. (2013). 'The Washington Consensus as transnational policy paradigm: Its origins, trajectory and likely successor'. Review of International Political Economy, 20(2), 268297.

Bednarik, M. K. (1966). 'The Moscow Bank: The International Bank for Economic Cooperation'. The American Review of Soviet and Eastern European Foreign Trade, 2(1): 3-8.

Ben-Artzi, Ruth. (2016). Regional development banks in comparison: Banking strategies versus development goals. New York: Cambridge University Press.

Bendor, J., Glazer, A. and Hammond, T. (2001). 'Theories of Delegation'. Annual Review of Political Science, 4: 235-69. 
Bhattacharya, A. and Kharas, H. (2016). The Role of Regional Development Banks in the New Global Agenda. Washington : Brookings.

Boitan, I. A. (2017). Examining the role of national promotional banks in the European economy: Emerging research and opportunities. Hershey, PA: IGI Global.

Buiter, W. H., \& Fries, S. M. (2002). What should the multilateral development banks do? London: European Bank for Reconstruction and Development.

Bussière, É., Dumoulin, M. and Willaert, É., eds. (2008). The Bank of the European Union. The EIB, 1958-2008. Luxembourg: European Investment Bank.

CAF-Banco de Desarrollo de América Latina (2016). 25 años de gestión. CAF.

Carrasco, E. R., Carrington, W., \& Lee, H. (2017). 'Governance and accountability: The regional development banks'. In Kwakwa, E. (ed.), Globalization and International Organizations. London: Routledge, pp. 81-140.

Carroll, T., Clifton, J. \& Jarvis, D. S. L. (2019) Power, leverage and marketization: the diffusion of neoliberalism from North to South and back again, Globalizations, 16:6, 771777.

Cherif, R., \& Hasanov, F. (2019a). The Return of the Policy That Shall Not Be Named: Principles of Industrial Policy. Wp 19/74. Washington: International Monetary Fund.

Cherif, R., \& Hasanov, F. (2019b). The Leap of the Tiger: Escaping the Middle-income 
Trap to the Technological Frontier. Global Policy, 10(4), 497-511.

Clifton, J., \& Díaz-Fuentes, D. (2014). 'Is the Organisation for Economic Co-operation and Development Ready for China?'. Emerging Markets Finance and Trade, 50: 21-36.

Clifton, J., Díaz-Fuentes, D. and Revuelta, J. (2014). 'Financing utilities: How the role of the European Investment Bank shifted from regional development to making markets'. Utilities Policy, 29: 63-71.

Clifton, J., Díaz-Fuentes, D. and Gómez, A. L. (2017a). 'The European Investment Bank: Development, Integration, Investment?' JCMS: Journal of Common Market Studies, 89(3): 733-750.

Clifton, J., Díaz-Fuentes, D., and Peña, A. L. G. (2017b). An Analysis of international financial organizations effectiveness. Revista de economía mundial, 47: 21-42.

Conway, P (1995). Currency Proliferation: The Monetary Legacy of the Soviet Union, Princeton: Princeton University Press.

Cook, L. D., \& Sachs, J. (1999). 'Regional public goods in international assistance.' In Kaul et al. (eds.), Global public goods: international cooperation in the 21st century, pp. 436-449.

Culpepper, R. (1994). Regional development banks: exploiting their specificity. Third World Quarterly, 15(3): 459-482. 
Culpepper, R. (1997). The Multilateral Development Banks: Titans or Behemoths?, Boulder, CO: Lynne Rienner, and Ottawa: The North-South Institute.

Desruelle, D. and Schipke, A., eds. (2008). Central America: economic progress and reforms. Washington: IMF.

Elsig, M. (2011). 'Principal-Agent Theory and the World Trade Organization: Complex Agency and "Missing Delegation". European Journal of International Relations, 17(3): 495-517.

European Commission (2015). 'Working together for jobs and growth: The role of National Promotional Banks (NPBs) in supporting the Investment Plan for Europe'. Communication from the Commission to the European Parliament and the Council, $\operatorname{COM}(2015) 361 . \quad$ Available at: $\quad$ https://eur-lex.europa.eu/legalcontent/en/TXT/?uri=CELEX\%3A52015DC0361. Accessed 28 February, 2020.

European Parliament (2016). 'New Financial Instruments and the Role of National Promotional Banks'. Study by Directorate General for Internal Policies. Policy Department D: $\quad$ Budgetary $\quad$ Affairs. Available at https://www.europarl.europa.eu/RegData/etudes/STUD/2016/572687/IPOL_STU(2016)5 72687_EN.pdf. Accessed on 28 February, 2020.

García, M. (2015). 'The European Union and Latin America: "Transformative power Europe" versus the realities of economic interests'. Cambridge Review of International Affairs, 28(4): 621-640. 
Griffith-Jones, S., and Cozzi, G. (2017). 'The roles of development banks; how they can promote investment, in Europe and globally'. In Noman, A. and Stiglitz, J.E. (eds.), Efficiency, Finance, and Varieties of Industrial Policy: Guiding Resources, Learning, and Technology for Sustained Growth. New York: Columbia University Press, pp. 131-155.

Griffith-Jones, S., and Tyson, J. (2013). The European Investment Bank: Lessons for Developing Countries (No. 2013/019). WIDER Working Paper.

Griffith-Jones, S., Griffith-Jones, D. and Hertova, D. (2008). Enhancing the Role of Regional Development Banks, G-24 Discussion Paper Series No. 50, July. UNCTAD: New York. Available at http://www20.iadb.org/intal/catalogo/PE/2009/02608.pdf. Accessed on 28 February 2020.

Griffith-Jones, S., and Ocampo, J. A. (eds.) (2018). The future of national development banks. Oxford: Oxford University Press.

Gurría, J. A., Volcker, P. A., and Birdsall, N. (2001). The Role of the Multilateral Development Banks in Emerging Market Economies: Findings of the Commission on the Role of the MDBs in Emerging Markets. Washington D.C.: Carnegie Endowment for International Peace.

Helleiner, E. (2017). The Latin American origins of Bretton Woods. In Margulis, M. (Eed.)The global political economy of Raúl Prebisch. Routledge, pp. 96-112.

Hawkins, D. and Jacoby, W. (2006). 'How Agents Matter'. In Darren Hawkins, David Lake, Daniel L. Nielson and Michael J. Tierney (eds.), Delegation and Agency in International 
Organizations. Cambridge: Cambridge University Press, pp. 199-228.

Hawkins, D., Lake, D., Nielson, D. and Tierney, M.J. (eds.) (2006). Delegation and Agency in International Organisations. Cambridge: Cambridge University Press.

Hoyer, W. (2015). The Investment Plan for Europe, Bridge Forum Dialogue, 27 October. Available at: https://forum-dialogue.lu/wp-content/uploads/discours-du-presidenthoyer.pdf. Accessed: 28 February 2020.

Humphrey, C. (2015). Developmental revolution or Bretton Woods revisited. London: Overseas Development Institute.

Humphrey, C. (2016). 'The Invisible Hand: Financial Pressures and Organisational Convergence in Multilateral Development Banks'. The Journal of Development Studies, 52(1): $92-112$

IMF (International Monetary Fund) (2018). Program Design in Currency Unions, Policy Paper. Washington: International Monetary Fund.

Kampffmeyer, T. (2000). A larger role for the RDBs. Briefing paper (3/2000). Bonn: German Development Institute.

Kawai, M., Morgan, P. J., \& Rana, P. B. (eds.) (2014). New global economic architecture: The Asian perspective. Cheltenham: Edward Elgar Publishing.

Kiewiet, D.R. and McCubbins, M.D. (1991). The Logic of Delegation: Congressional 
Parties and the Appropriations Process. Chicago: University of Chicago Press.

Kollatz-Ahnen, M. (2015). 'The rise of state investment banks'. In XX (ed.), MissionOriented Finance for Innovation. New Ideas for Investment-Led Growth. London, New York: Rowman \& Littlefield, pp. 111-118.

Krasner, S. D. (1981). 'Power Structures and Regional Development Banks'. International Organization 35(2): 303-28.

Lustig, N. (1997). 'The United States to the rescue: financial assistance to Mexico in 1982 and 1995'. Cepal Review.

Lyne, M.M., Nielson, D.L. and Tierney, M.J. (2006). 'Who Delegates? Alternative Models of Principals in Development Aid', in D. Hawkins, D. Lake, D.L. Nielson and M.J. Tierney (eds.), Delegation and Agency in International Organizations. Cambridge: Cambridge University Press, pp. 41-76.

Marichal, C. (2011). Los antecedentes históricos de la creación del Banco Interamericano de Desarrollo: reflexiones a partir del archivo de Eduardo Villaseñor. Mexico City: El Colegio de México.

Marlow, J. (2016). 'National investment banks: a radical proposal?' Open Democracy, 6 September. Available at https://www.opendemocracy.net/john-marlow/nationalinvestment-banks-radical-proposal. Accessed 22 February 2019.

Martin, L. (2006). 'Distribution, Information, and Delegation to International 
Organizations: The Case of IMF Conditionality’. In D. Hawkins, D. Lake, D.L. Nielson and M.J. Tierney (eds.), Delegation and Agency in International Organizations. Cambridge: Cambridge University Press, pp. 140-64.

Mazzucato, M., \& Penna, C. C. (2016). 'Beyond market failures: The market creating and shaping roles of state investment banks'. Journal of Economic Policy Reform, 19(4): 305326.

McCubbins, M. and Schwartz, T. (1984). 'Congressional Oversight Overlooked: Police Patrols versus Fire Alarms', American Journal of Political Science, 28(1): 165-79.

Mertens, D. and Thiemann, M. (2019). 'Building a hidden investment state? The European Investment Bank, national development banks and European economic governance.' Journal of European Public Policy, 26(1): 23-42.

Mertens, D., \& Thiemann, M. (2018). Market-based but state-led: The role of public development banks in shaping market-based finance in the European Union. Competition \& Change, 1024529418758479

Mertens, D., Thieman, M. and Volberding, P. (forthcoming). The making of European field of Development Banking. Oxford: Oxford University Press.

Naqvi, N., Henow, A. and Change, H.-J. (2018). 'Kicking Away the Financial Ladder: German Development Banking under Economic Globalisation'. Review of International Political Economy, 25(5): 672-698. 
Nielson, D.L. and Tierney, M.J. (2003) 'Delegation to International Organizations: Agency Theory and World Bank Environmental Reform'. International Organization, 57(2): 24176.

ODI (Overseas Development Institute) (1991). The Inter-American Development Bank and changing policies for Latin America. London: Overseas Development Institute.

ODI (1992). The African Development Bank: Facing new challenges.

London: Overseas Development Institute.

ODI (1996). Rethinking the role of multilateral development banks.

London: Overseas Development Institute.

ODI (2015). Multilateral development banks in the 21st century: three perspectives on China and the Asian Infrastructure Investment Bank. London: Overseas Development Institute.

OECD (2010). Perspective on Global Development. Shifting Wealth. Paris: OECD.

OECD (2019). Perspective on Global Development. Rethinking Development Strategies. Paris: OECD.

Oliver, R. W. (1971). Early Plans for a World Bank (No. 29). International Finance Section, Princeton University.

Perraudin, W., Powell, A. and Yang, P. (2016). 'Multilateral Development Bank Ratings 
and Preferred Creditor Status'. IADB working paper. XX: IADB.

Pinder, D.A. (1986). 'Small Firms, Regional Development and the European Investment Bank'. Journal of Common Market Studies, 24(3): 171-186.

Pisaneschi, M. L. (2004). Significance of the European Investment Bank, Graduate Theses and Dissertations, University of South Florida, Scholar Commons.

Rana, P. B. (2014). From a centralized to a decentralized global economic architecture: An overview. New Global Economic Architecture, 11. In Kawai et al eds. New global economic architecture: The Asian perspective. Cheltenham: Edward Elgar Publishing.

Ravallion, M. (2016). The World Bank: Why it is still needed and why it still disappoints. Journal of Economic Perspectives, 30(1), 77-94.

Robinson, N. (2009). 'The European Investment Bank: The EU's Neglected Institution'. Journal of Common Market Studies, 47(3): 651-73.

Rodrik, D. (1995). 'Why is there multilateral lending?' (No. w5160). Washington: National Bureau of Economic Research.

Schiavone, G. (1997). International Organizations. A dictionary (4rd Ed.) London: Macmillan.

Schröder, K. (1982). 'The IMF and the countries of the Council for Mutual Economic Assistance'. Intereconomics, 17(2): 87-90. 
Stiglitz, J. E. (1998). 'International financial institutions and the provision of international goods'. EIB Papers, 3(2): 116-132

Singer, H. W. (1995). 'An historical perspective'. In XX (ed.), The UN and the Bretton Woods Institutions. Basingstoke: Palgrave Macmillan, pp. 17-25.

Singer, D. (2007). Regulating Capital: Setting Standards for the International Financial System. Ithaca: Cornell University Press.

Singh, M. (1969). 'Regional Development Banks'. International Conciliation, 38, 1.No. 576. (January).

Tussie, D. (1995). Inter-American Development Bank, Vol. 4. Collection 'The Multilateral Banks’, Boulder/Ottawa: Lynne Rienner Publishers, The North-South Institute.

Vaubel, R. (2006). 'Principal-agent problems in international organizations'. Review of International Organizations, 1: 125-138.

Vestergaard, J. and Wade, R. H. (2013). 'Protecting power: how Western states retain the dominant voice in the World Bank's governance'. World Development, 46: 153-164.

Volberding, P. (2016). National Development Banks and the Rise of Market-Based Protectionism in Europe. CEEISA-ISA 2016 Joint International Conference, Ljubljana.

Wang, H. (2017). 'New multilateral development banks: opportunities and challenges for 
global governance'. Global Policy, 8(1): 113-118.

Wang, H. (2019). The New Development Bank and the Asian Infrastructure Investment Bank: China's Ambiguous Approach to Global Financial Governance. Development and Change, 50(1), 221-244.

Weingast, B.R and Moran, M.J. (1983). 'Bureaucratic Discretion or Congressional Control?'. Journal of Political Economy, 91: 765-800.

White, J. (1970). Regional Development Banks. A study of institutional style. London: Overseas Development Institute.

White, J. (1972). Regional Development Banks: The Asian, African and Inter-American Development Banks. New York: Praeger.

Wieser, T., Alonso, J. A., Barbut, M., Berglof, E., Dominik, J., Kleiterp, N., Kloppenburg, N., Passacantando, F., and Ulbaek, S. (2019). Europe in the World: The future of the European Financial Architecture for Development. October. Brussels: General Secretariat of the Council of the EU. Economic and Financial Affairs.

Woods, N. (2006). The Globalizers: The IMF, the World Bank, and Their Borrowers. Ithaca: Cornell University Press.

$\mathrm{Xu}$, J. (2017). Beyond US Hegemony in International Development: The Contest for Influence at the World Bank. Cambridge: Cambridge University Press. 
$\mathrm{Xu}$, J. (this volume). 'The Asian Infrastructure Investment Bank: Its birth, Mandates and Infrastructure Planning'. In (eds) J. Clifton, D. Díaz-Fuentes \& D. Howarth.

Regional Development Banks in the World Economy. Oxford University Press.

Williamson, J. (2000). 'What Should the World Bank Think about the Washington Consensus?'. The World Bank Research Observer, 15(2): 251-264. 